\title{
On the Effect of Land Use Change on the Meteorological Parameters above the Greater Athens Area
}

\author{
Fameli K.M. ${ }^{*}$, Assimakopoulos V.D. ${ }^{2}$, Kotroni V. ${ }^{2}$ \\ 1 Division of Environmental Physics and Meteorology, Department of Physics, University of \\ Athens, Building Physics V, University Campus, Athens, 157 84, Greece \\ 2 Institute for Environmental Research and Sustainable Development, National Observatory \\ of Athens, Athens, Greece \\ *corresponding author e-mail: kmfameli@phys.uoa.gr
}

\begin{abstract}
The rapid land use changes that took place in the Greater Athens Area (GAA) the past decades, due to the expansion of the urban grid, have changed the landscape of Attica significantly. Areas that were covered by low vegetation in the past are now replaced by roads (e.g. Attiki Odos) and new towns. On the other hand, accurate and updated data of land use are necessary for simulating the meteorological fields above urban areas, which in turn are given as input to photochemical models in order to study the dispersion of pollutants above urban areas. The purpose of the present work is to study the effects of land use changes on the meteorological parameters, such as wind speed profiles and temperature. For this reason, the meteorological mesoscale model MM5 was applied, using updated land use data. The model ran with the grid nesting method using two grids, the fine one covering the GAA with a spatial resolution of $5 \times 5 \mathrm{~km}^{2}$. Results showed that the land use changes affected wind and temperature fields. Wind velocities decreased above areas covered by urban grid that were previously characterised as shrub land, while above the rapidly developing eastern suburbs of Attica an increase in velocities appeared.
\end{abstract}

\section{Introduction}

Rapid Land Use/Land Cover (LULC) changes that take place in urban areas affect the local environment and human activities to such extent that updating data sets used in meteorological models is necessary in order to simulate accurately the current state (Lee et al. 2009). In many studies the relationship between land use change and meteorological fields, such as wind velocity and direction and surface temperature, has been described (Civerolo et al. 2000, Tokairin et al. 2010). As for the Greater Athens Area (GAA), the land use changes that occurred the past 
decade due to the organization of the Olympic Games of 2004 and the population shift to the eastern areas of Attica, is not well represented in the traditional LULC data sets used by meteorological models. Moreover, meteorological data used in photochemical models affect the predicted pollutants concentrations (Jackson et al. 2006) so the development of accurate meteorological fields is of great importance. The purpose of the present study is to examine the contribution of the LULC updated data on the meteorological pattern with the use of the mesoscale meteorological model MM5 for the GAA.

\section{Meteorological Model Description}

For the present study the meteorological simulations were performed with MM5, a widely used non-hydrostatic, primitive equation model using terrain-following coordinates. The model setup for the physical parameterizations includes: the combination of Kain-Fritsch (Kain and Fritsch 1993) convective scheme, with the highly efficient and simplified microphysical scheme proposed by Schultz (1995), and the MRF scheme proposed by Hong and Pan (1996) for the boundary layer.

For the simulations performed, two one-way nested grids were used: Grid1 ( $220 \times 180$ grid points with a $15-\mathrm{km}$ horizontal grid increment) covering most of Europe, the Mediterranean and the northern African coast, Grid2 (52 x 46 grid points, $5-\mathrm{km}$ grid spacing) covering the entire Athens area and the adjacent water bodies. In the vertical direction, twenty-three unevenly spaced full sigma levels are selected, $(\sigma=1 ., 0.99,0.98,0.96,0.93,0.89,0.85,0.80,0.75,0.70,0.650 .60$, $0.55,0.50,0.45,0.40,0.35,0.30,0.25,0.20,0.15,0.10,0.05,0.00)$. For the initialization and nudging of the boundaries of Grid1 the European Centre of Medium Range Weather Forecasts (ECMWF) analyses at 0.5- degree lat/lon horizontal grid increment were used. Finally the topography and land cover (25categories) were derived from the 30 -arcsec global USGS global coverage file.

\section{Methodology}

The simulation period started at 00.00 (UTC) on June 19th, 2006 and ended at 24.00 (UTC) on June 19th, 2006. The temporal resolution was 120 minutes for Grid1 and 60 minutes for Grid2. MM5 ran for two land use cases: A) LULC data provided by USGS Global LULC v.2.0 Database were used for the year 1992 and B) an updated land use field for the fine grid was used (Fig. 1). 

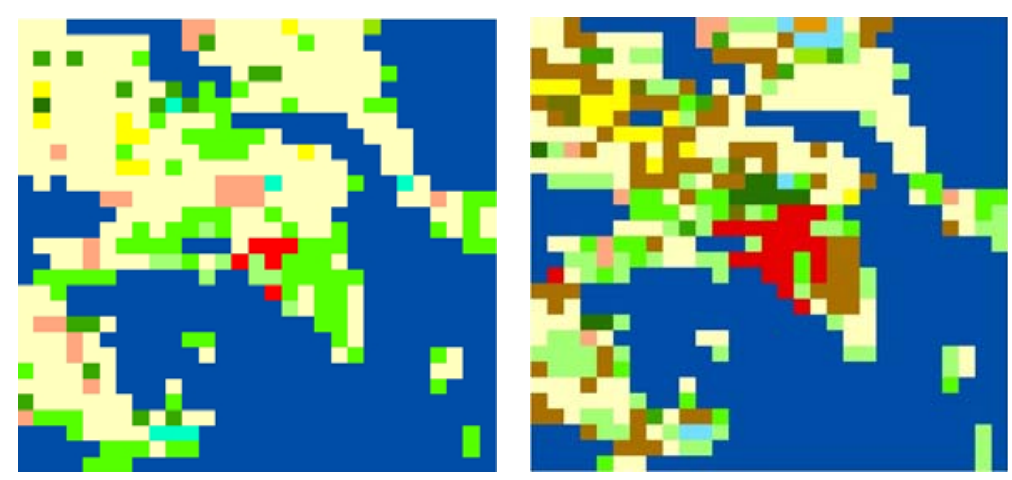

USGS LULC Categories

$\begin{array}{ll}1 \text { Urban and Built-Up Land } & \\ 2 \text { Dryland Cropland and Pasture } & 9 \text { Shrubland } \\ \square & 9 \text { Mixed Shrubland/Grassland } \\ & \text { Irrigated Cropland and Pasture } \\ 4 \text { Mixed Dryland/Irrigated Cropland and Pasture } & 10 \text { Savanna } \\ 5 \text { Cropland/Grassland Mosaic } & 11 \text { Deciduous Broadleaf Forest } \\ \square \text { Cropland/Woodland Mosaic } & 14 \text { Evergreen Needleleaf Forest } \\ 7 \text { Grassland } & 15 \text { Mixed Forest } \\ & 16 \text { Water Bodies }\end{array}$

Fig. 1. USGS LULC field (1992) (left), updated LULC field (2006) (right).
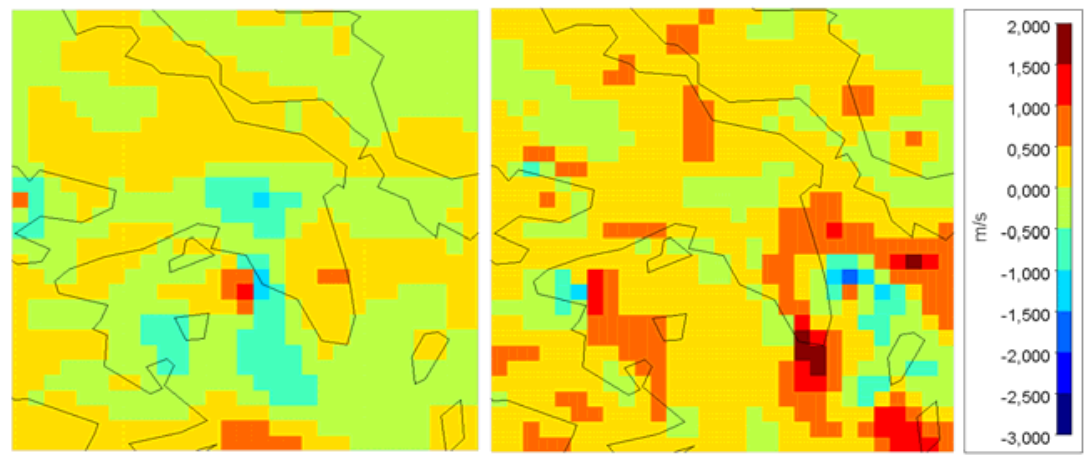

Fig. 2. Difference in wind velocity between the updated and the old LULC fields, at 6.00 UTC (left) and 15.00 UTC (right).

The updating process was fulfilled only for the fine grid having 29 cells on each direction. Each cell was assigned one land use type based upon the predominant category within that cell. The land use classes are depicted in table 1. From the 25- LULC categories only 13 describe this study area of interest. It is obvious from Figs 2 and 3 that areas previously covered by low vegetation are now covered by urban land in the GAA and cells covered by irrigated croplands have increased in Boeotia and NE Peloponnese. 
Table 1. Description of selected LULC USGS categories and physical parameters for N.H. summer (15 April-15 October).

\begin{tabular}{lllllll}
\hline $\begin{array}{l}\text { LU } \\
\text { Value }\end{array}$ & $\begin{array}{l}\text { Land use } \\
\text { category }\end{array}$ & $\begin{array}{l}\text { Albedo Moisture } \\
(\%)\end{array}$ & $\begin{array}{l}\text { Avail. } \\
(\%)\end{array}$ & $\begin{array}{l}\text { Emissivity } \\
(\% \text { at } 9 \mu \mathrm{m})\end{array}$ & $\begin{array}{l}\text { Roughness } \\
\text { Length }(\mathrm{cm})\end{array}$ & $\begin{array}{l}\text { Thermal Inertia } \\
\left(\mathrm{cal} \mathrm{cm}^{-2} \mathrm{k}^{-1} \mathrm{~s}^{-1 / 2}\right)\end{array}$ \\
\hline 1 & Urban & 15 & 10 & 88 & 80 & 0.03 \\
2 & Drylnd Crop. Past. & 17 & 30 & 98.5 & 15 & 0.04 \\
8 & Shrubland & 37.2 & 39.2 & 41.9 & 10 & 0.03 \\
15 & Mixed Forest & 13 & 30 & 94 & 50 & 0.04 \\
16 & Water Bodies & 8 & 100 & 98 & .01 & 0.06 \\
\hline
\end{tabular}

\section{Results}

The new land use field modified the surface roughness of the area significantly and as a consequence meteorological parameters such as wind velocity and direction were affected. To illustrate the effects of the land use changes, the wind velocity differences were plotted; case B - case A (Fig. 2).

Generally, the wind velocity decreased in urban cells previously covered by low vegetation as the surface roughness length is higher for the urban class (80 $\mathrm{cm}$ - class $1,15 \mathrm{~cm}$ - class 2 ). The decrease was mainly noticed in the morning and varied from $0.1 \mathrm{~m} / \mathrm{s}$ to $1 \mathrm{~m} / \mathrm{s}$. A great change in wind velocity appeared above urban areas at the edges with coastal ones (Piraeus, Fig. 3a), as the previously low surface in combination with the sea favored the development of higher velocities, or to the NE suburbs of the GAA as shown in Fig.3b. Wind velocity in urban areas whose land use category was unchanged was also affected thanks to the increase of the urban grid (Fig. 3c). It is worth mentioning that during the simulation period low winds occurred (about $1-5 \mathrm{~m} / \mathrm{s}$ ) so changes in land use played a significant role to the development of the new wind field.

On the other hand, wind velocity increased at eastern Attica due to the fact that areas previously characterized as cropland/ woodland mosaic are now croplands and pastures (Fig. 3d). Differences in wind direction appeared at the southern edges of the urban grid with the Saronic Gulf where a shift from NW to NNW was made (not shown here).

The expansion of the urban grid led to a small rise in temperature at the NE suburbs of the GAA (Fig. 4). On the contrary, regarding the new land use field, urban cells close to the sea appeared to be cooler. In the Mesogia Plain, the surface temperature was higher by $2 \mathrm{~K}$ on average, which may be attributed to the 
decreased soil moisture availability (35\% at USGS land use field $-25 \%$ at the updated land use field).
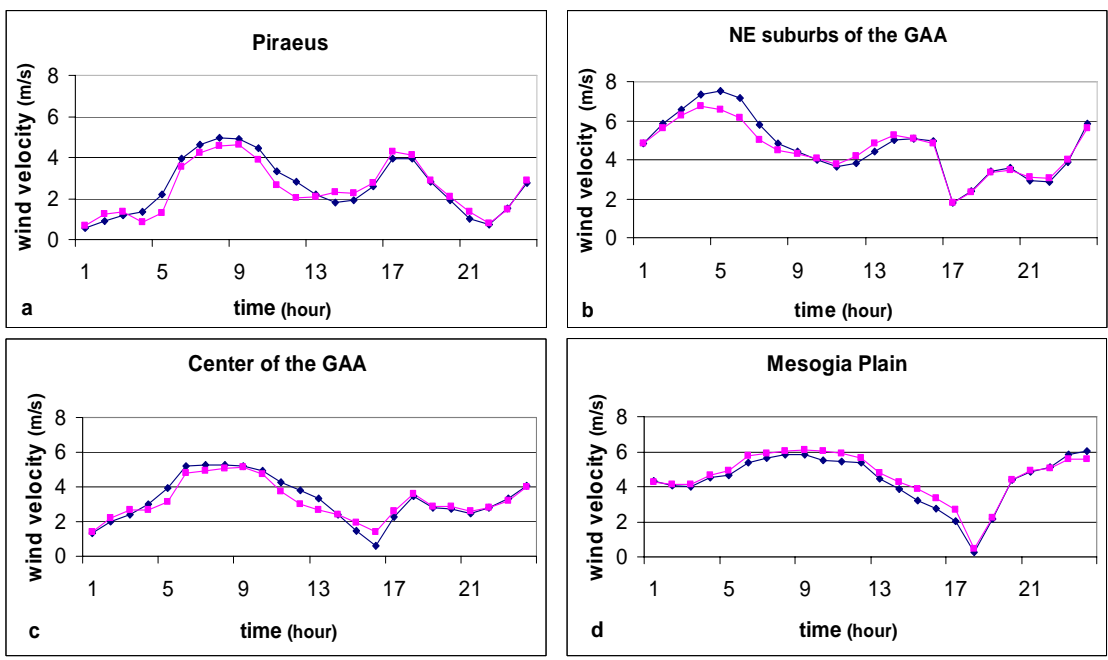

USGS_1992 - - updated_2006

Fig. 3. Wind velocity for the old and the updated LULC fields at selected cells.
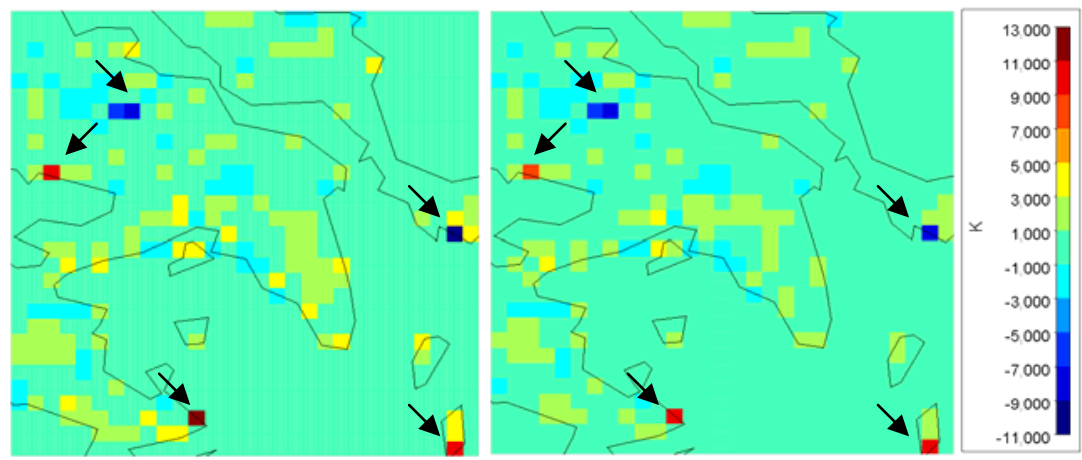

Fig. 4. Difference in temperature between the updated and the old LULC fields, at 6.00 UTC (left) and 15.00 UTC (right)- at cells pointed with arrows the land use changed from sea to land and vice versa so temperature appeared to have the major differences at these areas $(\sim 10 \mathrm{~K})$.

\section{Conclusions}

In the present study the effects of updated land use input data to the MM5 model were examined. The most important results may be summarized as follows: 
- The wind velocity decreased while its direction presented a shift due to the expansion of the urban grid.

- The surface temperature at areas of the GAA that underwent rapid urbanization increased by $2 \mathrm{~K}$.

- The meteorological parameters changed significantly at the border between cells whose land use category was unchanged with the ones where new data existed.

Concluding, land use patterns should be taken into consideration when using models in order to simulate meteorology as the latter is sensitive to the surface characteristics, thus affecting input data given to photochemical models

Acknowledgments This research has been co-financed by the European Union (European Social Fund - ESF) and Greek national funds through the Operational Program "Education and Lifelong Learning" of the National Strategic Reference Framework (NSRF) - Research Funding Program: Heracleitus II. Investing in knowledge society through the European Social Fund.

\section{References}

Civerolo KL, Sistla G, Rao ST, Nowak DJ (2000) The effects of land use in meteorological modeling: implications for assessment of future air quality scenarios. Atmos Environ 34:1615-1621. doi: 10.1016/S1352-2310(99)00393-3

Hong SY and Pan HL (1996) Nonlocal boundary layer vertical diffusion in a medium - range forecast model. Mon Weather Rev 124:2322-2339. doi:10.1175/1520-0493(1996)124<2322: NBLVDI $>2.0 . \mathrm{CO} ; 2$

Jackson B, Chau D, Gurer K, Kaduwela A (2006) Comparison of ozone simulations using MM5 and CALMET/MM5 hybrid meteorological fields for the July/August 2000 CCOS episode. Atmos Environ 40:2812-2822. doi:10.1016/j.atmosenv.2006.01.020

Kain, JS, Fritsch JM (1993) Convective parameterization for mesoscale models: The KainFritsch scheme. The Representation of Cumulus in numerical models. Meteor Mon 46 Amer. Met Soc 165-177

Lee SM, Princevac M, Mitsutomi S, Cassmassi J (2009) MM5 simulations for air quality modeling: An application to a coastal area with complex terrain. Atmos Environ 43:447-457. doi:10.1016/j.atmosenv.2008.07.067

Schultz P (1995) An explicit cloud physics parameterization for operational numerical weather prediction. Mon Weather Rev 123:3331-3343. doi:10.1175/1520-0493(1995)123<3331: $\mathrm{AECPPF}>2.0 . \mathrm{CO} ; 2$

Tokairin T, Sofyan A, Kitada T (2010) Effect of land use changes on local meteorological conditions in Jakarta, Indonesia: toward the evaluation of the thermal environment of megacities in Asia. Int J Climatol 30:1931-1941. doi:10.1002/joc.2138 